\title{
Impact of Antigen Presentation Mechanisms on Immune Response in Autoimmune Hepatitis
}

\author{
Rossella Fasano ${ }^{1,2+}$, Eleonora Malerba ${ }^{1+}$, Marcella Prete ${ }^{1}$, Antonio Giovanni Solimando ${ }^{1,2}$, \\ Alessio Buonavoglia ${ }^{1}$, Nicola Silvestris ${ }^{1,2}$, Patrizia Leone ${ }^{1 \neq}$ and Vito Racanelli ${ }^{1 \text { *f }}$ \\ ${ }^{1}$ Department of Biomedical Sciences and Human Oncology, "Aldo Moro" University of Bari Medical School, Bari, Italy, ${ }^{2}$ Medical \\ Oncology Unit, Istituto di Ricovero e Cura a Carattere Scientifico (IRCCS) Istituto Tumori Giovanni Paolo II, Bari, Italy
}

OPEN ACCESS

Edited by:

Elodie Segura,

Institut Curie, France

Reviewed by:

Rodrigo Liberal,

King's College London,

United Kingdom

Emmanuel L. Gautier,

Institut National de la Santé et de la

Recherche Médicale (INSERM),

France

*Correspondence:

Vito Racanell

vito.racanelli1@uniba.it

${ }^{t}$ These authors have contributed equally to this work and share first authorship

${ }^{\ddagger}$ These authors share last authorship

Specialty section: This article was submitted to Antigen Presenting Cell Biology, a section of the journal

Frontiers in Immunology

Received: 12 November 2021 Accepted: 31 December 2021 Published: 18 January 2022

Citation:

Fasano R, Malerba E, Prete $M$, Solimando AG, Buonavoglia A, Silvestris $N$, Leone $P$ and Racanelli $V$

(2022) Impact of Antigen

Presentation Mechanisms on Immune Response in Autoimmune Hepatitis.

Front. Immunol. 12:814155. doi: 10.3389/fimmu.2021.814155
The liver is a very tolerogenic organ. It is continually exposed to a multitude of antigens and is able to promote an effective immune response against pathogens and simultaneously immune tolerance against self-antigens. In spite of strong peripheral and central tolerogenic mechanisms, loss of tolerance can occur in autoimmune liver diseases, such as autoimmune hepatitis $(\mathrm{AlH})$ through a combination of genetic predisposition, environmental factors, and an imbalance in immunological regulatory mechanisms. The liver hosts several types of conventional resident antigen presenting cells (APCs) such as dendritic cells, B cells and macrophages (Kupffer cells), and unconventional APCs including liver sinusoidal endothelial cells, hepatic stellate cells and hepatocytes. By standard (direct presentation and cross-presentation) and alternative mechanisms (cross-dressing and MHC class II-dressing), liver APCs presents self-antigen to naive T cells in the presence of costimulation leading to an altered immune response that results in liver injury and inflammation. Additionally, the transport of antigens and antigen:MHC complexes by trogocytosis and extracellular vesicles between different cells in the liver contributes to enhance antigen presentation and amplify autoimmune response. Here, we focus on the impact of antigen presentation on the immune response in the liver and on the functional role of the immune cells in the induction of liver inflammation. A better understanding of these key pathogenic aspects could facilitate the establishment of novel therapeutic strategies in $\mathrm{AlH}$.

Keywords: autoimmune hepatitis, major histocompatibility complex class II, major histocompatibility complex class I, antigen processing and presentation, liver

\section{INTRODUCTION}

The liver is an important immunological organ with the unique capacity to mount effective immune responses against hepatotropic pathogens on one hand and maintain a local and systemic immune tolerance to self and foreign antigens on the other (1). The liver's immune function is strongly influenced by its exclusive anatomy and by its cell composition (1). The liver hosts both conventional such as dendritic cells (DCs), B cells and macrophages (Kupffer cells, KCs), and unconventional antigen presenting cells (APCs) including liver sinusoidal endothelial cells (LSECs), 
hepatic stellate cells (HSCs), and hepatocytes (HCs) which uptake antigens, process and present them to $\mathrm{CD} 4^{+}$and $\mathrm{CD} 8^{+}$ $\mathrm{T}$ cells by canonical and noncanonical mechanisms resulting in initiation and amplification of immune responses or in induction of immune tolerance $(1,2)$. When this equilibrium is disrupted, the immune tolerance is lost developing autoimmune liver diseases such as autoimmune hepatitis (AIH) $(1,2)$. Moreover, intercellular transfer of the peptide-major histocompatibility complexes (MHCs) via trogocytosis and extracellular vesicles (EVs) can confer to any cell APC features, albeit with different outcomes. Upon self-antigen presentation by liver APCs, the activation of a variety of immune cells such as Th0-, Th1- and Th2-CD $4^{+} \mathrm{T}$ cells, Th17 cells, cytotoxic $\mathrm{CD}^{+} \mathrm{T}$ cells, regulatory $\mathrm{T}$ cells (Treg), natural killer (NK) cells and B cells, along with the release of cytokines including interferon (IFN)- $\gamma$, transforming growth factor- $\beta$ (TGF- $\beta$ ), interleukin (IL)-10, IL-21, IL-2 and autoantibodies results in autoimmune attack of liver in AIH.

The pathogenesis of AIH is complex and so far not fully understood. Growing evidence suggests that molecular mimicry and enhanced autoantigen presentation contribute to trigger autoimmune response resulting in the activation of autoreactive lymphocytes.

Current treatments for AIH focus on non-specific immunosuppressive drugs and do not rely on the immune pathology underlying the autoimmune response. A better understanding of the impact of alternative antigen presentation mechanisms on the immune response in the liver and of the functional role of the immune cells in the induction of liver inflammation could facilitate the establishment of novel therapeutic strategies in $\mathrm{AIH}$ (3). The development of antigenspecific immunotherapy aiming to manipulate antigen presentation and reprogram APCs towards a tolerant phenotype may represent effective therapeutic strategies for treatment of refractory AIH.

\section{AUTOIMMUNE HEPATITIS}

$\mathrm{AIH}$ is a rare acute or chronic inflammatory liver disease clinically presenting with high levels of circulating autoantibodies, hypergammaglobulinemia, elevated serum aminotransferase levels and interface hepatitis on histological examination with a lymphoplasmacytic infiltrate (4). According to the autoantibodies detected at diagnosis can be identified two subsets of AIH: type 1 autoimmune hepatitis (AIH-1), defined by the presence of anti-nuclear antibody (ANA) and/or anti-smooth muscle antibody (SMA), and type 2 autoimmune hepatitis (AIH2) associated with positivity for anti-liver/kidney-microsomalantibody-type-1 (anti-LKM-1) or anti-liver-cytosol-type-1 (antiLC1) autoantibodies $(3,5)$. Clinical presentations are variable; patients may be asymptomatic, chronically ill, or present with acute or fulminant liver failure (3). Concurrent autoimmune diseases are frequently observed (6). Incidence and prevalence vary according to age, gender, ethnicity, and geographical region (7). Based on European studies, the annual incidence ranges from 0.9 to 2.0 cases per 100,000 persons and the annual prevalence ranges from 11 to 25 cases per 100,000 individuals, depending on the geographical location (8). AIH occurs globally in all ethnicities and affects children and adults of all ages. AIH-1 displays a bimodal age pattern at presentation, with one peak during childhood or adolescent and the other in the adulthood around the age of 40 years. AIH-2 is typical of pediatric ages and is rare in adults (9). As many autoimmune diseases, AIH has a female predominance $(3,7)$.

The precise etiology of AIH remains unknown. Along with genetic, epigenetic and environmental factors, pathogenic mechanisms such as molecular mimicry, altered antigen presentation, and dysregulated immune responses against liver autoantigens can lead to immune tolerance breakdown $(3,10-$ 22) (Figure 1). Existing therapies for AIH are based on nonspecific immunosuppressive drugs and do not consider key immunopathological aspects underlying the initiation and perpetuation of the autoimmune response. Among these, the presentation of self-antigenic peptides from liver APCs to T cells deserves to be explored. Therefore, increasing knowledge about mechanisms of antigen presentation could help to design novel therapeutic strategies to reestablish immunological tolerance and to treat unstable or refractory AIH.

\section{INITIATION OF THE AUTOIMMUNE RESPONSE}

The mechanisms underlying AIH pathogenesis are not fully elucidated, although there is growing evidence that molecular mimicry and enhanced autoantigen presentation are involved in the induction of the autoimmune response resulting in the activation of autoreactive lymphocytes.

\section{Molecular Mimicry}

"Molecular mimicry" is a process where a foreign antigen shares sequence or structural similarities with self-antigens leading to autoimmunity. In this case, the immune system can be confused by the foreign antigen which induces an immune response towards similar self-antigens (23). Viral infections have been reported to be risk factors for $\mathrm{AIH}$ and several mouse models for AIH demonstrated that molecular mimicry is a prerequisite for breaking cell tolerance in the liver (24-26). During chronic hepatitis $\mathrm{B}$ virus $(\mathrm{HBV})$ and hepatitis $\mathrm{C}$ virus (HCV) infections, approximately $50 \%$ of patients develop autoantibodies such as ANA and SMA as a consequence of cross-reactive immune reactions between host smooth muscle/nuclear components and HCV antigens $(27,28)$. Moreover, $10 \%$ of chronic HCV patients reported to be positive for anti-LKM-1 autoantibodies. This positivity is due to a high amino acid sequence homology between HCV polyprotein and cytochrome P450 2D6 (CYP2D6), the target of anti-LKM-1 antibodies $(29,30)$.

\section{Antigen Presentation}

Professional APCs are able to process intracellular and extracellular pathogens through different pathways. In the MHC class I antigen presentation pathway, endogenous 


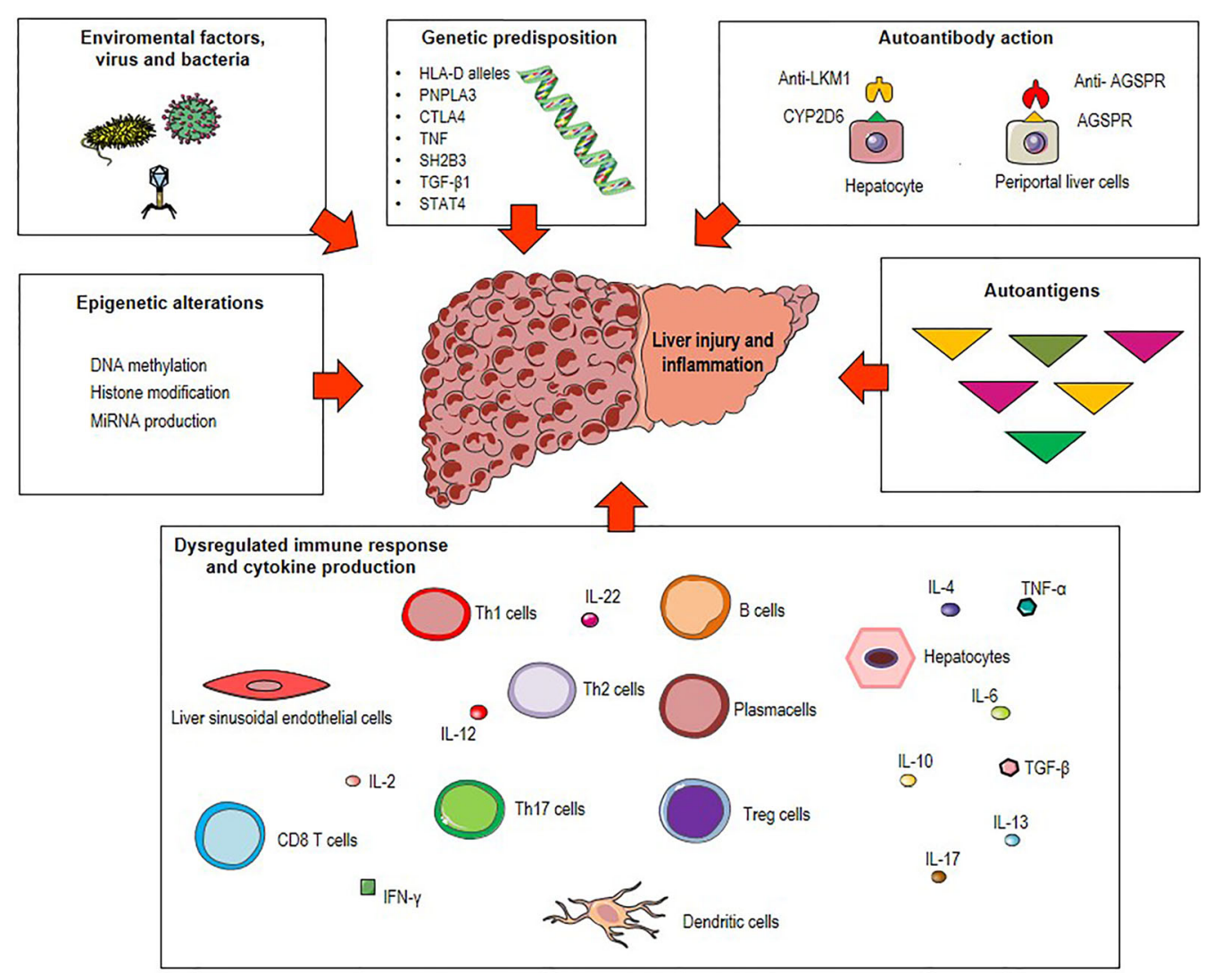

FIGURE 1 | Possible triggers of autoimmune hepatitis (AlH). Environmental factors (microbial products, drugs metabolites), epigenetic alterations (DNA methylation, histone modification and miRNA production) and genetic predisposition including polymorphisms of the human leukocyte antigen (HLA) genes (HLA class II DRB1 alleles), the Src homology 2-B adaptor protein 3 gene (SH2B3), the patatin-like phospholipase domain-containing protein 3 (PNPLA3), the cytotoxic T lymphocyteassociated antigen 4 (CTLA4), the tumor necrosis factor (TNF), the transforming growth factor- $\beta 1$ (TGF- $\beta 1$ ) and the signal transducer and activator of transcription (STAT) 4 are associated with great risk of developing AlH. Combination of these factors with pathogenetic mechanisms such as molecular mimicry, autoantibody production and dysregulated immune responses against liver autoantigens lead to immune tolerance breakdown and consequent liver injury and inflammation.

antigens are digested by the proteasome (an intracellular protease complex) and presented by MHC class I molecules to $\mathrm{CD}^{+} \mathrm{T}$ cells to induce a cell-killing response. In the MHC class II antigen presentation pathway, exogenous antigens are engulfed by APCs such as DCs, digested in the phagolysosome and presented by MHC class II molecules to $\mathrm{CD}^{+}{ }^{+} \mathrm{T}$ cells to stimulate a helper response $(31,32)$. Antigen presentation can take place in the following direct and indirect ways: 1) direct presentation, 2) cross-presentation, 3) cross-dressing and 4) MHC class II dressing (Figure 2). 1) Direct presentation occurs when the APC such as DC is infected by a virus and the endogenous viral proteins are broken down in the cytosol into peptides that, through the MHC class I antigen presentation pathway, bind to endogenous MHC class I molecules and are presented to naive $\mathrm{CD}^{+} \mathrm{T}$ cells to generate virus-specific cytotoxic $\mathrm{CD}^{+} \mathrm{T}$ cells. 2) Cross-presentation arises when exogenous antigens, such as viruses do not infect professional APC, are engulfed by DC, escape from phagosomes to enter the cytosol and gain access to MHC class I molecules to stimulate $\mathrm{CD}^{+} \mathrm{T}$ cells (33). 3) Cross-dressing takes place by intercellular transfer of the peptide-MHC class I complex from an APC or tumor cell to a DC through trogocytosis, exosomes or tunneling nanotubes. This process results in activation of cytotoxic $\mathrm{CD}^{+} \mathrm{T}$ cells and is defined as "DC cross-dressing" (34). 4) MHC class II dressing occurs when the exogenous peptide-MHC class II complex is transferred (through trogocytosis/exosomes) from DCs to nearby cells such as DCs, CD4 ${ }^{+}$T cells, or type 2 innate immune cells. This intercellular transfer involves two live cells, requires cell-to-cell contact and result in $\mathrm{CD} 4^{+} \mathrm{T}$ cell activation (34-36). All the antigen presentation mechanisms mentioned above are involved in the pathogenesis of AIH.

\section{Direct Presentation and Cross-Presentation in $\mathrm{AlH}$}

In normal conditions, the liver displays a tolerogenic capacity resulting from a combined effort of immune cells, parenchyma cells, epithelial and endothelial cells and microenvironment. Because of the high local concentrations of the immunosuppressive cytokine IL-10, the majority of liver APCs, including DCs, LSECs, KCs and HCs, have low levels of MHC class II and the co-stimulatory molecules CD80/CD86, thus 


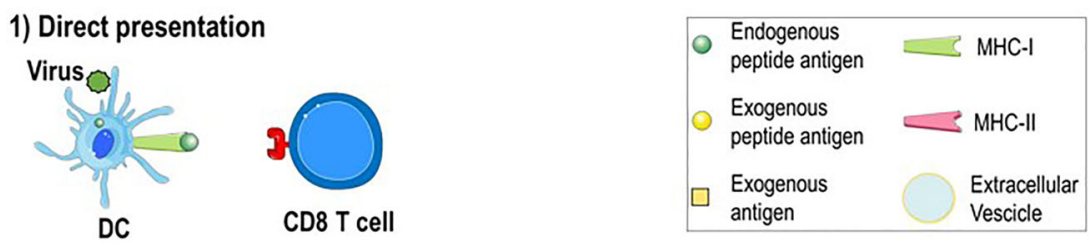

2) Cross-presentation

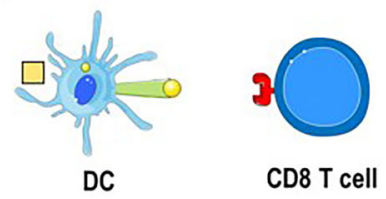

3) Cross-dressing

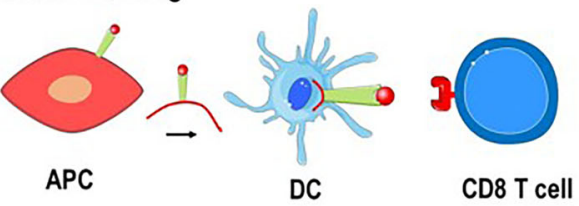

4) MHC-II dressing

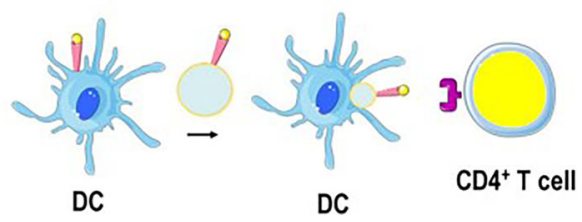

FIGURE 2 Mechanisms of antigen presentation in the liver. 1) Direct presentation. Within virus-infected DC, the endogenous antigen is broken down into peptides that bind to endogenous MHC class I molecules and are presented to antigen-specific CD8 ${ }^{+} \mathrm{T}$ cells. 2) Cross-presentation. An exogenous antigen, such as a virus that do not infect DC, is engulfed by DC, processed and derived peptide antigens are presented to CD8 ${ }^{+} \mathrm{T}$ cells through $\mathrm{MHC}$ class I molecules. 3 ) Cross-dressing. The peptide-MHC class I complex is transferred from APC to DC by trogocytosis or extracellular vesicles. 4) MHC-\| dressing. The peptide-MHC class II complex is transferred (through trogocytosis/extracellular vesicles) from DC to neighboring DC which can use it to activate CD4 ${ }^{+} \mathrm{T}$ cells.

exhibit an immature phenotype which induces immune tolerance (3). The priming of hepatic $\mathrm{CD}^{+}{ }^{+} \mathrm{T}$ cell leads to the induction of tolerogenic Foxp $3^{+}$and Foxp $3^{+} \mathrm{IL}-10^{+} \mathrm{CD} 4^{+}$Tregs which further release IL-10 augmenting the immune suppressive milieu (37-40). In addition, hepatic $\mathrm{CD}^{+} \mathrm{T}$ cell priming induces deletion of premature and nonantigen-specific $\mathrm{CD} 8^{+} \mathrm{T}$ cells (2). The effect of $\mathrm{T}$ cell priming, however, depends also on the overall antigen load; when the antigen density is low, $\mathrm{T}$ cells are activated and an effector response is initiated, whereas when the antigen load is high, $\mathrm{T}$ cell priming results in $\mathrm{T}$ cell anergy and exhaustion due to the great expression on the surface of the programmed cell death protein 1 (PD-1) (2). Moreover, the site of primary $\mathrm{T}$ cell activation influences the outcome of intrahepatic $\mathrm{CD}^{+} \mathrm{T}$ cell responses. Using a transgenic mouse model in which antigen is expressed within both liver and lymph nodes, Bowen et al. demonstrated that $\mathrm{CD}^{+} \mathrm{T}$ cells primed within lymph nodes generated an effective intrahepatic antigenspecific immune response, whereas $\mathrm{CD} 8^{+} \mathrm{T}$ cells activated within the tolerogenic environment of the liver induced a defective cytotoxic immune response and showed a short half-life (41). During autoimmune diseases such as $\mathrm{AIH}$, a breakdown in hepatic tolerance takes place (42). The trigger underlying the switch towards an overwhelming immune response against autoantigens is still unknown. From an immunological view, the autoantigen presentation by conventional and unconventional liver APCs, the unsuccessful control of autoreactive $\mathrm{T}$ cells and the production of autoantibodies play a crucial role $(43,44)$. Dysregulated Treg cells which are also susceptible to Fas ligand-mediated apoptosis can be observed within the liver of AIH patients (45-48). Moreover, during AIH, beyond their function as autoantibody-secreting cells, B cells can act as potent APCs activating autoreactive $\mathrm{CD} 4^{+} \mathrm{T}$ cells through the MHC class II antigen presentation pathway $(49,50)$. This B$\mathrm{T}$ cell interaction generates a vicious cycle, a positive feedback loop in which autoreactive B cells as APC activate $\mathrm{CD}^{+} \mathrm{T}$ cells which in turn stimulate $B$ cells leading to their terminal differentiation in immunoglobulin-producing plasma cells and to amplification of autoimmunity (51). The importance of B cells as APC in AIH pathogenesis is suggested by B cell depletion with anti-CD20 antibody in mouse models. Anti-CD20 antibody treatment significantly reduced expression of MHC class II and CD80 on B cells with consequent diminished capacity of 
autoantigen presentation to $\mathrm{T}$ cells and reduction of $\mathrm{T}$ cell activation and proliferation (52). Moreover, a single dose of anti-CD20 antibody was able to induce remission of liver inflammation, reduced hepatocytes lysis and consequent lowered autoantigen release (52).

\section{Cross-Dressing and MHC-II Dressing in AlH}

The context in which the MHC complexes are expressed impacts the outcome of T cell priming. During homeostasis, HCs exhibit only MHC class I molecules on their surface. During infectious and autoimmune liver diseases, such as AIH, the inflamed microenvironment induces the aberrant expression of $\mathrm{MHC}$ class II molecules by HCs, which acquire the capacity to perform antigen-presenting cell functions (53) and to elicit Th1 or Th2 effector responses (54). However, the acquired capacity of HCs to present antigen on MHC class II molecules is not sufficient to cause AIH (54). Further investigations are required to clarify the increased risk for $\mathrm{AIH}$ conferred by the expression of certain human leukocyte antigen (HLA)-DR and HLA-DQ loci $(14,15)$.

During $\mathrm{AIH}$, trogocytosis can occur between MHC class IIexpressing $\mathrm{HCs}$ and $\mathrm{CD}^{+} \mathrm{T}$ cells in a TCR dependent manner resulting in peptide-MHC class II transfer onto $\mathrm{CD}^{+} \mathrm{T}$ cells and dying HCs that lose part of the hepatocyte membrane $(55,56)$ (Figure 3A). This process named piecemeal necrosis is characterized by necrosis of periportal HCs with inflammation extending from the portal tract into the periportal zone (57). The transfer of peptide-MHC class II complexes along with costimulatory molecules, such as CD80/CD86 to $\mathrm{CD}^{+} \mathrm{T}$ cell, can enable $\mathrm{T}$ cell to act as APC, inducing naïve $\mathrm{T}$ cell activation and amplification of the effector $\mathrm{T}$ cell response. In the absence of co-stimulatory signals, tolerance is established leading to $\mathrm{T}$ cell apoptosis and hyporesponsiveness (43).
Extracellular vesicles (EVs) are an alternative way of transferring cellular content from one cell to another (58). EVs are lipid bilayer vesicles originating from different cell types. Based on their size, they can be distinguish in exosomes (50-150 $\mathrm{nm})$, microvesicles (100-1000 nm) and apoptotic bodies (500$2000 \mathrm{~nm}$ ) (59). EVs/exosomes can be equipped with a multitude of molecules and soluble factors with immunomodulatory functions. In the liver, after binding to target cells such as APCs, EVs/exosomes carrying peptide-MHC class II complexes are taken up by endocytosis and can induce three different immune responses (Figure 3B): 1) the peptide-MHC class II complex is directly presented by the APC to $\mathrm{CD} 4^{+} \mathrm{T}$ cell eliciting $\mathrm{T}$ cell priming in an immunological synapse that involves co-stimulatory molecules; 2 ) the peptide-MHC class II complex is processed by the APC, and the antigen peptide is bound to the MHC class II molecules of APC, and presented to $\mathrm{CD}^{+} \mathrm{T}$ cell to elicit indirect antigen presentation and $\mathrm{T}$ cell priming; 3) after the processing of the peptide-MHC class II complex, the antigen peptide is bound to the MHC class II molecules of APC and the new peptide-MHC class II complex is released by the APC by EVs that could transfer the complex to remote cells transferring antigen presenting ability (43).

Beside peptide-MHC class II complexes, liver EVs/exosomes can also carry Fas ligand (FasL/CD95L) that communicates cell death signals when it binds to its receptor, Fas/CD95, integrins, the asialoglycoprotein receptor usually expressed by HCs, as well as soluble factors like TGF- $\beta$ and TNF- $\alpha$ (60-62).

EVs and trogocytosis make possible also the transfer of the MHC class I molecules. During viral infections, intercellular transfer of MHC class I molecules has been observed in the liver from the HSCs to LSECs. Such transfer supports LSEC crosspresentation of antigens to CD8 $\mathrm{T}$ cells reinforcing the cytotoxic $\mathrm{T}$ cell response (63). It is yet unclear whether this mechanism

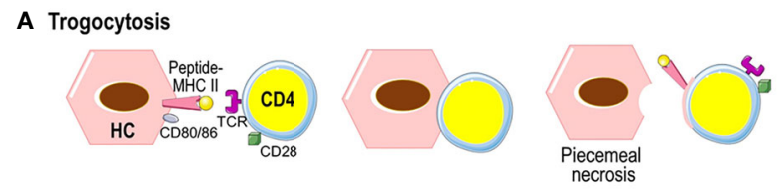

B Extracellular vesicles

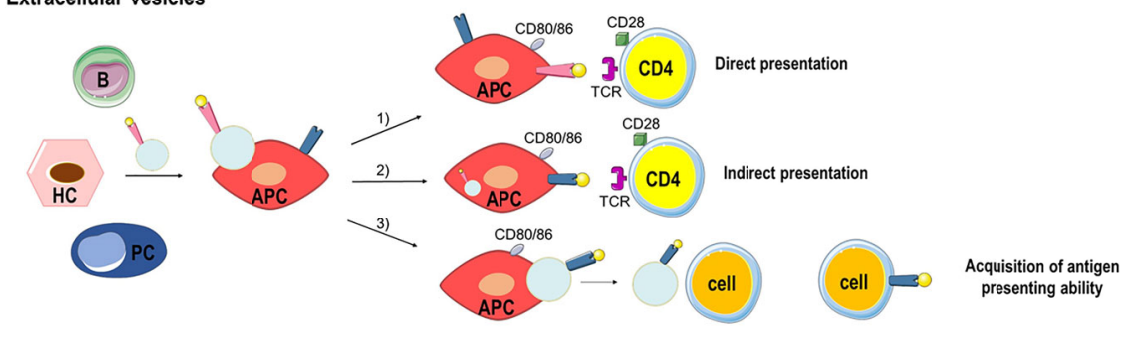

FIGURE 3 | Examples of peptide-MHC complex transfer by trogocytosis or extracellular vesicles. (A) Trogocytosis between MHC class II-expressing HCs and CD4 $\mathrm{T}$ cells resulting in the transfer of the membrane fragment with the peptide-MHC class II complex to CD4 ${ }^{+} \mathrm{T}$ cells. $\mathrm{HCs}$ that lose part of their membrane go to death (piecemeal necrosis). (B) All parenchymal and nonparenchymal cells produces extracellular vesicles. Extracellular vesicles bearing peptide-MHC class II complexes are taken up by APC triggering three separate immune responses: 1) direct presentation of antigen and priming of $\mathrm{CD} 4^{+} \mathrm{T}$ cells. 2 ) the peptide-MHC class II complex is processed by the APC, and the antigen peptide is bound to the MHC class II molecules of APC to elicit indirect antigen presentation and CD4 ${ }^{+} \mathrm{T}$ cell priming. 3 ) after the processing the antigen peptide is bound to the MHC class II molecules of APC and the new peptide-MHC class II complex is transferred through extracellular vesicles to other cells which acquire antigen presenting ability. 
occurs also during liver autoimmune disease such as $\mathrm{AIH}$ sustaining the priming of autoreactive CD8 T cells (43).

\section{Immune Cells Activated Upon Self-Antigen Presentation}

During $\mathrm{AIH}$, the processing and presentation of self-antigens by liver APC initiates the immune response through the activation of both naive $\mathrm{CD}^{+}{ }^{+} \mathrm{T}$ helper (Th0) cells and $\mathrm{CD} 8^{+}$effector $\mathrm{T}$ cells in the presence of co-stimulatory molecules as CD80/86 on APC and CD28 on $\mathrm{T}$ cells (64). Upon activation, $\mathrm{CD} 4^{+} \mathrm{Th} 0$ cells can differentiate into various $\mathrm{T}$ helper cell populations according to the cytokines in the microenvironment and the nature of the antigen.

A microenvironment with high levels of transforming growth factor- $\beta$ (TGF- $\beta$ ) promotes differentiation of Th0 cells into Treg cells; the predominance of IL- 12 supports the differentiation of Th0 lymphocytes into Th1 cells, whereas an IL-4-rich milieu favors the differentiation into Th2 cells. Furthermore, TGF- $\beta$, IL-1, and IL-6 promote differentiation into T helper 17 (Th17) cells (3). Each cell subset releases cytokines which lead to a cascade of events culminating with the autoimmune attack of hepatocytes (Figure 4).

Treg cells are key players in autoimmune diseases including AIH. Functional impairment and altered frequency of Treg cells in AIH patients cause breakdown of self-tolerance mechanisms (46) with consequent beginning and progression of autoimmune liver injury $(44,65)$. In patients with $\mathrm{AIH}$, the frequency of circulating Treg cells and their ability to suppress $\mathrm{T}$ cell proliferation are lower than in healthy subjects, especially at diagnosis and during relapses than during drug-induced remission (66-68). Treg cells are characterized by the expression of markers associated with the acquisition of regulatory properties, including Foxp3, CTLA4 and the glucocorticoid-induced TNF receptor, CD62 ligand.

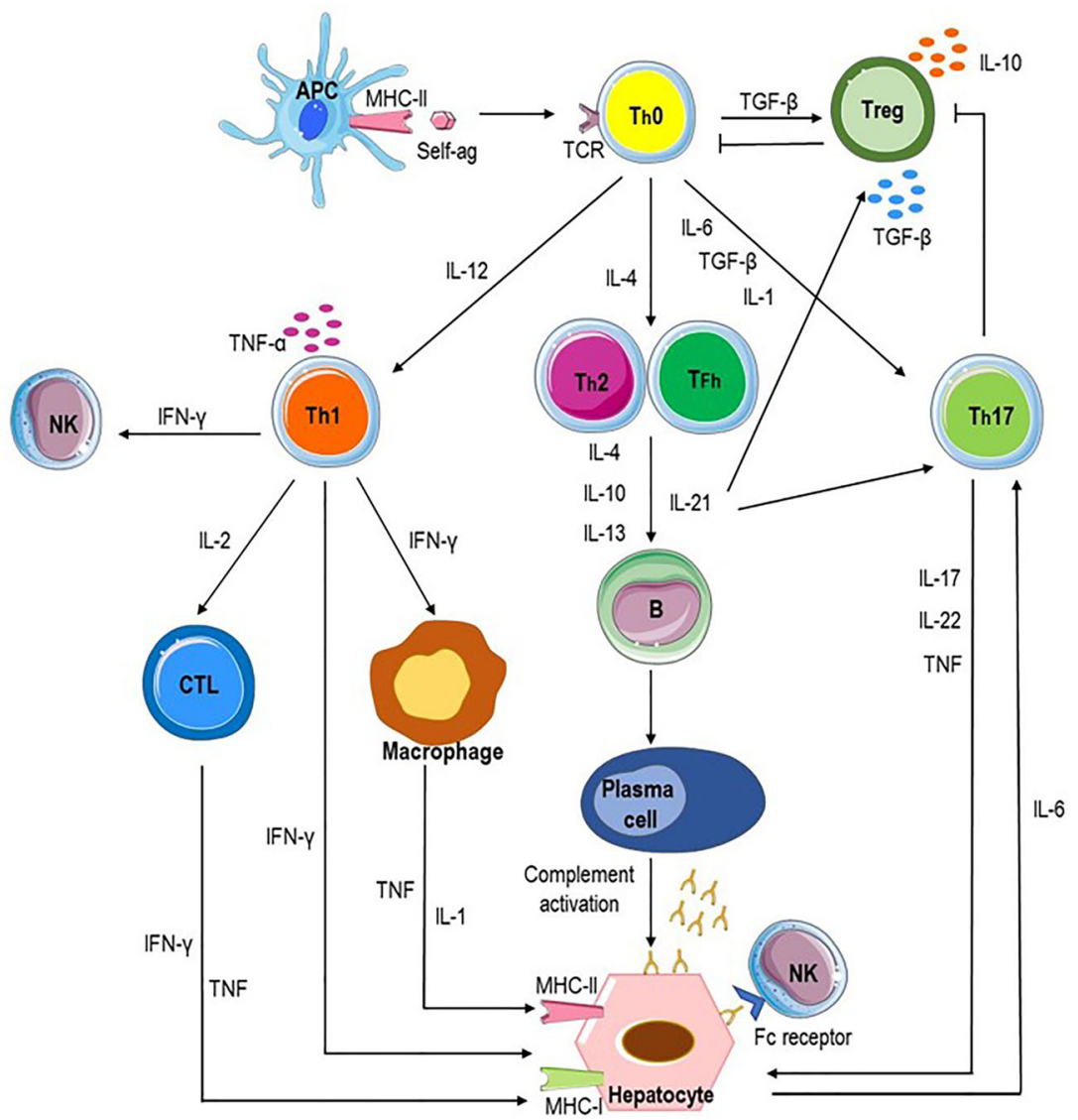

FIGURE 4 | Potential pathways of autoimmune attack of hepatocytes in AlH. Autoimmune-mediated liver damage in AlH is likely induced by an immune response to liver autoantigens. Antigen-presenting cells (APC) present autoantigenic peptide to naive CD4 ${ }^{+} \mathrm{T}$ helper cells (Th0), which release proinflammatory cytokines (IL-1, IL4, IL-12, IL-6, and transforming growth factor beta, TGF- $\beta$ ) resulting in the differentiation of regulatory T cells (Treg), Th1, Th2, and Th17 cells. Each cell subset releases cytokines which lead to a cascade of events culminating with the autoimmune attack of hepatocytes. Liver cell destruction could derive from the activation of cytotoxic T lymphocytes (CTL) through cytokines released by Th1 and activated macrophages; Th2 cells secrete IL-4, IL-10, and IL-13 which trigger B cell maturation into plasma cells which produce autoantibodies and induce antibody-dependent cellular cytotoxicity and complement activation. Th17 cells release proinflammatory cytokines such as IL-17, IL-22, and tumor necrosis factor alpha (TNF- $\alpha$ ), inhibit Treg cells and stimulates hepatocytes to secrete IL-6 which further amplifies Th17 cell activation. Tfh (T follicular helper) cells participate to activation and differentiation of B cells in antibody-secreting plasma cells and release IL-21, a regulator of Treg cell differentiation and Th17 cell expansion. 
Importantly, they express little or no IL-7 receptor (CD127). They act by direct contact with the target cells and by secreting inhibitory cytokines, such as IL-10 and TGF- $\beta$ (69). Moreover, the expression of the ectoenzyme CD39 in concert with CD73/ecto-5'-nucleotidase distinguishes on Treg cells and the adenosine A2A receptor on activated effector $\mathrm{T}$ cells creates immunosuppressive loops (70-72). It has been shown that $\mathrm{CD} 9^{+}$Treg cells are reduced in $\mathrm{AIH}$ patients, fail to adequately hydrolyze proinflammatory nucleotides, and do not effectively suppress IL-17 production by effector $\mathrm{CD} 4^{+} \mathrm{T}$ cells (73). In addition, CD $39^{+}$Treg cells are plastic and unstable in the presence of proinflammatory stimuli switching from Treg to effector cells, and decreasing further Treg frequency (73).

Th1 cell differentiation results in the secretion of IL-2, INF- $\gamma$ and TNF- $\alpha$ and in the activation of cytotoxic $C D 8^{+}$T lymphocytes (CTLs) which, after interaction with antigens presented by the MHC class Iantigenic peptide complexes on hepatocytes, attack hepatocytes causing liver damage $(10,74,75)$. INF- $\gamma$ is a crucial mediator of tissue damage since it not only stimulates $\mathrm{CD}^{+} \mathrm{T}$ cells, increases the expression of MHC class I, and promotes aberrant expression of MHC class II molecules on hepatocytes, making them able to present antigens on their surface, thus enhancing $T$ cell activation and perpetuating liver damage (44). Moreover, INF- $\gamma$ activates monocytes/macrophages, which in turn release IL- 1 and TNF- $\alpha$ (76) and enhances NK cell activity (77). AIH-2 patients are characterized by higher percentage of peripheral blood $\mathrm{CD}^{+} \mathrm{T}$ cells producing IFN- $\gamma$ at diagnosis than during effective immunosuppressive treatment (78) and by liver inflammatory infiltrate rich in IFN- $\gamma$-producing Th1 cells (79). AIH2 patients have liver inflammatory infiltrates rich in Th1 cells producing TNF- $\alpha$ (10).

Th2 cells release IL-4, IL-10, and IL-13 which trigger B cell maturation into plasma cells secreting autoantibodies which can cause liver injury through antibody-dependent cellular cytotoxicity and complement activation (80). The presence of plasma cells in the damaged liver and of circulating autoantibodies are a key feature of $\mathrm{AIH}$ and are used as diagnostic and classification markers (81) (Table 1). Furthermore, the expression on the surface of hepatocytes of CYP2D6, the target of anti-LKM1 autoantibodies exposes them to direct humoral immune assault (82).

Th17 cells produce proinflammatory cytokines such as IL-17, IL-22, and TNF- $\alpha$, support the autoimmunity process through inhibition of Treg and stimulates hepatocytes to secrete IL-6 which further amplifies Th17 cell activation (83, 84). Their number correlates with the severity of liver fibrosis (84).

New evidence suggests a role of Tfh ( $T$ follicular helper) cells in the AIH pathogenesis (85). Tfh cells are a subset of helper $\mathrm{CD}^{+} \mathrm{T}$ cells which, through the production of IL-21 and the expression of costimulatory molecules such as CD40 ligand, are able to induce the activation and differentiation of $\mathrm{B}$ cells in mature plasma cells secreting immunoglobulins. IL-21 is a regulator of Treg differentiation and function through the mTOR pathway, drives Th17 expansion (86) and promotes differentiation of Tfh cells by autocrine signaling (87). Dramatically high serum levels of IL-21 are found in severe $\mathrm{AIH}$ patients and correlate with disease activity $(88,89)$. Furthermore, Tfh cells generate crucial signals that regulate the affinity maturation of germinal center $B$ cells and alterations in their numbers and functions are involved in the loss of self-tolerance (90).

$\gamma \delta$ T cells in patients with AIH release high amount of IFN- $\gamma$ and granzyme B contributing to liver damage (66), although further investigations are needed to clarify their role. Clonal analysis experiments revealed the presence of both alphabeta $(\alpha \beta)$ and gammadelta $(\gamma \delta)$ T cells in peripheral blood and liver biopsies from AIH patients. Specifically, the majority of clones obtained from the peripheral blood are $\mathrm{CD} 4^{+}$T cells bearing the $\alpha \beta$ T cell receptor $(\alpha \beta$ TCR), while the largest numbers of clones generated from liver biopsies of the same patients are $\mathrm{CD} 4{ }^{-} \mathrm{CD} 8^{-}$cells bearing the $\gamma \delta \mathrm{TCR}$ or $\mathrm{CD}^{+} \alpha \beta \mathrm{T}$ cells (91). $\gamma \delta \mathrm{T}$-cell clones obtained from the peripheral blood and the portal areas of pediatric AIH patients show cytolytic activity against hepatocytes $(91,92)$.

\section{TREATMENT OF AIH}

Most AIH patients treated with current therapies show longterm complete response to treatment, but remain under lifelong immunosuppressive therapy. About $10-20 \%$ of patients do not respond to current therapy and display disease progression to cirrhosis and end-stage liver disease $(81,93)$. Moreover, current treatments as well as biological therapies such as anti-TNF (infliximab) and anti-CD20 (rituximab), although effective, are associated with serious side effects due to the specific drug or the broad immunosuppression (93-95).

TABLE 1 | Autoantibodies in AlH.

\begin{tabular}{|c|c|c|c|}
\hline AUTOANTIBODY & TARGET ANTIGEN & DISEASE & PERCENTAGE \\
\hline ANA & Chromatin, histones, centromeres, (ds) and (ss) DNA, cyclin A, ribonucleoprotein & $\mathrm{AlH}-1$ & $50-70 \%$ \\
\hline SMA & F-actin, actin, tubulin, intermediate filaments & $\mathrm{AlH}-1$ & $50 \%$ \\
\hline Anti-LKM-1 & Cythocrome P4502D6 & $\mathrm{AlH}-2$ & $85 \%$ \\
\hline Anti-LKM-3 & Uridine-diphosphate-glucuronosyl-transferase & $\mathrm{AlH}-2$ & rare \\
\hline Anti-SLA/LP & O-phosphoseryl-tRNA: selenocysteine-tRNA synthase (SepSecS) & $\begin{array}{l}\mathrm{AlH}-1 \\
\mathrm{AlH}-2\end{array}$ & $10-20 \%$ \\
\hline p-ANCA & Various cytoplasmatic antigens & $\mathrm{AlH}-1$ & $36-50 \%$ \\
\hline Anti-LC-1 & Forminotransferase cyclodeaminase & $\mathrm{AlH}-2$ & $30 \%$ \\
\hline Anti-ASGP-R & Asialoglycoprotein receptor & $\begin{array}{l}\mathrm{AlH}-1 \\
\mathrm{AlH}-2\end{array}$ & $24-82 \%$ \\
\hline
\end{tabular}

AlH, autoimmune hepatitis; ANA, antinuclear antibody; SMA, anti-smooth muscle antibody; Anti- LKM-1, anti-liver/kidney-microsomal-antibody-type-1; Anti-LKM-3, anti-liver/kidneymicrosomal-antibody-type-3; Anti-SLA/LP, anti-soluble liver antigen/liver pancreas antigen; $p$-ANCA, perinuclear anti-neutrophil cytoplasmic antibody; anti-LC-1, anti-liver cytosolic antigen type 1; Anti-ASGP-R, anti-asialoglycoprotein receptor; ds, double strands; ss, single strand. 
Ongoing clinical trials are evaluating new therapeutic options aiming at targeting $\mathrm{B}$ lymphocytes or expanding regulatory $\mathrm{T}$ cells to restore immune tolerance. The AMBER study (ADCC Mediated B-Cell depletion and BAFF-R Blockade, NCT03217422, phase 2/3) is the first randomized double-blind, placebo-controlled trial that is assessing the safety and efficacy of the anti-BAFFR antibodies (Ianalumab, VAY736) in adults with $\mathrm{AIH}$ not responding to standard therapies (https://clinicaltrials. gov/ct2/show/NCT03217422). Further trials are evaluating the possible use of anti-BAFF drugs, such as belimumab (96), in refractory AIH patients with advanced fibrosis.

The expansion and therapeutic application of polyclonal Tregs is currently a treatment option for AIH-1. An ongoing uncontrolled, open label phase I/IIa clinical trial (NCT01988506) is investigating the employ of low-dose IL-2 therapy to enhance Treg functions in autoimmune and inflammatory diseases including AIH. Preliminary results in two AIH patients displayed Treg expansion and activation, without effector $\mathrm{T}$ cell activation, and with a good safety (97). In vitro experiments have shown the chance to generate antigen-specific Tregs from AIH-2 patients able to suppress cytotoxic activity by $\mathrm{CD}^{+} \mathrm{T}$ cells (98). Nevertheless, further investigations are required to maintain a stable and functional Treg phenotype in the inflammatory liver microenvironment.

Better knowledge of antigen presentation mechanisms in $\mathrm{AIH}$ may also open new therapeutic avenues. For example, antigen specific immunotherapy designed to manipulate antigen presentation and restore immunological self-tolerance to hepatic autoantigens leaving the rest of the immune system to function successfully are evaluating in mouse models (99) and are described in the section future directions.

\section{FUTURE DIRECTIONS}

Future orientation in successful therapies in AIH and others autoimmune disorders will be the detection and isolation of autoreactive $\mathrm{T}$ cells, the manipulation of antigen presentation and the education of liver-resident APCs and effector T cells (43, 100). Flow cytometry and peptide-MHC complex tetramers have been the gold standard for detecting antigen-specific $\mathrm{CD}^{+}$and $\mathrm{CD}^{+} \mathrm{T}$ cells for more than two decades (101). In mouse models of AIH (Ad-hFTCD-infected NOD mice) (102) it has been demonstrated that engineered peptide-MHC complex-coated nanoparticles loaded with relevant $\mathrm{AIH}$ specific peptides activated and expanded cognate $\mathrm{CD}^{+}$type 1 regulatory $(\operatorname{Tr} 1)$ $\mathrm{T}$ cells and regulatory $\mathrm{B}$ cells, and reduced liver inflammation, fibrosis, and alanine aminotransferase (ALT) levels without compromise immunity against viruses (vaccinia, influenza), intracellular bacteria (Listeria), or metastatic (liver) allogeneic tumors (102-104).

\section{REFERENCES}

1. Racanelli V, Rehermann B. The Liver as an Immunological Organ. Hepatology (2006) 43(2 Suppl 1):S54-62. doi: 10.1002/hep.21060
In addition, the delivery of autoantigen peptides to LSECs by nanoparticles can induce antigen-specific Tregs enable to control autoimmunity in mice (105). Furthermore, naturally produced and modified EVs equipped with a variety of molecules could be innovative and strong weapons for transport of drugs to the liver $(58,106)$, and for manipulating antigen presentation and reprogramming APCs towards a tolerant phenotype, educating immune cells such as T cells through the expression of PD-L1 or suppressive cytokines.

\section{CONCLUSIONS}

A better understanding of the pathogenetic mechanisms underlined the autoimmune attack to the liver during $\mathrm{AIH}$, with special attention to the antigen presentation processes that trigger the immune response in the liver could suggest new therapeutic strategies for the treatment of $\mathrm{AIH}$ patients. Cross-presentation, trogocytosis, cross dressing and EVs are tools which provide crucial regulatory mechanisms to enhance antigen presentation in the liver, to trigger tolerance or inflammation in $\mathrm{AIH}$.

The design of nanoparticles coated with peptide-MHC complex presenting disease antigens and engineered EVs could facilitate regulation of immune cell activation in a diseasespecific manner. Therefore, the detection of disease-related antigens and antibody-secreting $\mathrm{B}$ cells, the fine-tuning of the antigen specific immunotherapy to reinstate immunological selftolerance could open new therapeutic strategies for treatment of AIH patients in order to specifically blocking liver auto-attack with few side effects.

\section{AUTHOR CONTRIBUTIONS}

Conceptualization, PL and VR. Data curation, RF, EM, AB, AS, and NS. Writing, RF, EM, and PL. Supervision, PL and VR. All of the authors reviewed the manuscript, approved the draft submission, and accept responsibility for all aspects of this study. All authors have read and agreed to the published version of the manuscript.

\section{FUNDING}

This work was supported by the Italian Association for Cancer Research (AIRC) through an Investigator Grant no. 20441 to VR. The sponsors of this study are non-profit organizations that support science in general. They had no role in gathering, analyzing, or interpreting the data.

2. Horst AK, Neumann K, Diehl L, Tiegs G. Modulation of Liver Tolerance by Conventional and Nonconventional Antigen-Presenting Cells and Regulatory Immune Cells. Cell Mol Immunol (2016) 13(3):277-92. doi: $10.1038 / \mathrm{cmi} .2015 .112$ 
3. Mieli-Vergani G, Vergani D, Czaja AJ, Manns MP, Krawitt EL, Vierling JM, et al. Autoimmune Hepatitis. Nat Rev Dis Primers (2018) 4:18017. doi: $10.1038 /$ nrdp.2018.17

4. Hennes EM, Zeniya M, Czaja AJ, Pares A, Dalekos GN, Krawitt EL, et al. Simplified Criteria for the Diagnosis of Autoimmune Hepatitis. Hepatology (2008) 48(1):169-76. doi: 10.1002/hep.22322

5. Liberal R, Longhi MS, Mieli-Vergani G, Vergani D. Pathogenesis of Autoimmune Hepatitis. Best Pract Res Clin Gastroenterol (2011) 25 (6):653-64. doi: 10.1016/j.bpg.2011.09.009

6. Vierling JM. Autoimmune Hepatitis and Overlap Syndromes: Diagnosis and Management. Clin Gastroenterol Hepatol (2015) 13(12):2088-108. doi: $10.1016 /$ j.cgh.2015.08.012

7. Czaja AJ. Review Article: Next-Generation Transformative Advances in the Pathogenesis and Management of Autoimmune Hepatitis. Aliment Pharmacol Ther (2017) 46(10):920-37. doi: 10.1111/apt.14324

8. Linzay CD, Sharma B, Pandit S. Autoimmune Hepatitis. In: StatPearls. Treasure Island (FL) (2021).

9. European Association for the Study of the Liver. EASL Clinical Practice Guidelines: Autoimmune Hepatitis. J Hepatol (2015) 63(4):971-1004. doi: 10.1016/j.jhep.2015.06.030

10. Bovensiepen CS, Schakat M, Sebode M, Zenouzi R, Hartl J, Peiseler M, et al. TNF-Producing Th1 Cells Are Selectively Expanded in Liver Infiltrates of Patients With Autoimmune Hepatitis. J Immunol (2019) 203(12):3148-56. doi: 10.4049/jimmunol.1900124

11. Chaouali M, Fernandes V, Ghazouani E, Pereira L, Kochkar R. Association of STAT4, TGFbeta1, SH2B3 and PTPN22 Polymorphisms With Autoimmune Hepatitis. Exp Mol Pathol (2018) 105(3):279-84. doi: 10.1016/j.yexmp.2018.10.001

12. Czaja AJ. Epigenetic Changes and Their Implications in Autoimmune Hepatitis. Eur J Clin Invest (2018) 48(4):e12899-919. doi: 10.1111/eci.12899

13. Czaja AJ. Examining Pathogenic Concepts of Autoimmune Hepatitis for Cues to Future Investigations and Interventions. World J Gastroenterol (2019) 25(45):6579-606. doi: 10.3748/wjg.v25.i45.6579

14. de Boer YS, van Gerven NM, Zwiers A, Verwer BJ, van Hoek B, van Erpecum KJ, et al. Genome-Wide Association Study Identifies Variants Associated With Autoimmune Hepatitis Type 1. Gastroenterology (2014) 147(2):443-52 e5. doi: 10.1053/j.gastro.2014.04.022

15. Engel B, Laschtowitz A, Janik MK, Junge N, Baumann U, Milkiewicz P, et al. Genetic Aspects of Adult and Pediatric Autoimmune Hepatitis: A Concise Review. Eur J Med Genet (2021) 64(6):104214. doi: 10.1016/j.ejmg. 2021.104214

16. Eskandari-Nasab E, Tahmasebi A, Hashemi M. Meta-Analysis: The Relationship Between CTLA-4 +49 a/G Polymorphism and Primary Biliary Cirrhosis and Type I Autoimmune Hepatitis. Immunol Invest (2015) 44(4):331-48. doi: 10.3109/08820139.2014.1003651

17. Li Y, He X, Schembri-King J, Jakes S, Hayashi J. Cloning and Characterization of Human Lnk, an Adaptor Protein With Pleckstrin Homology and Src Homology 2 Domains That can Inhibit T Cell Activation. J Immunol (2000) 164(10):5199-206. doi: 10.4049/ jimmunol.164.10.5199

18. Mederacke YS, Mederacke I. Editorial: PNPLA3 Genotype and Liver Diseases-More Than Non-Alcoholic Fatty Liver Disease. Authors' Reply. Aliment Pharmacol Ther (2020) 52(2):391-2. doi: 10.1111/apt.15873

19. Pingitore P, Dongiovanni P, Motta BM, Meroni M, Lepore SM, Mancina RM, et al. PNPLA3 Overexpression Results in Reduction of Proteins Predisposing to Fibrosis. Hum Mol Genet (2016) 25(23):5212-22. doi: $10.1093 / \mathrm{hmg} / \mathrm{ddw} 341$

20. Qin B, Li J, Liang Y, Yang Z, Zhong R. The Association Between Cytotoxic T Lymphocyte Associated Antigen-4, Fas, Tumour Necrosis Factor-Alpha Gene Polymorphisms and Autoimmune Hepatitis: A Meta-Analysis. Dig Liver Dis (2014) 46(6):541-8. doi: 10.1016/j.dld.2014.02.003

21. Takaki S, Tezuka Y, Sauer K, Kubo C, Kwon SM, Armstead E, et al. Impaired Lymphopoiesis and Altered B Cell Subpopulations in Mice Overexpressing Lnk Adaptor Protein. J Immunol (2003) 170(2):703-10. doi: 10.4049/ jimmunol.170.2.703

22. Webb GJ, Hirschfield GM, Krawitt EL, Gershwin ME. Cellular and Molecular Mechanisms of Autoimmune Hepatitis. Annu Rev Pathol (2018) 13:247-92. doi: 10.1146/annurev-pathol-020117-043534
23. Bogdanos DP, Choudhuri K, Vergani D. Molecular Mimicry and Autoimmune Liver Disease: Virtuous Intentions, Malign Consequences. Liver (2001) 21(4):225-32. doi: 10.1034/j.1600-0676.2001.021004225.x

24. Christen U, Hintermann E. Pathogens and Autoimmune Hepatitis. Clin Exp Immunol (2019) 195(1):35-51. doi: 10.1111/cei.13203

25. Ehser J, Holdener M, Christen S, Bayer M, Pfeilschifter JM, Hintermann E, et al. Molecular Mimicry Rather Than Identity Breaks T-Cell Tolerance in the CYP2D6 Mouse Model for Human Autoimmune Hepatitis. J Autoimmun (2013) 42:39-49. doi: 10.1016/j.jaut.2012.11.001

26. Hintermann E, Ehser J, Christen U. The CYP2D6 Animal Model: How to Induce Autoimmune Hepatitis in Mice. J Vis Exp (2012) 60:e3644-51. doi: $10.3791 / 3644$

27. Gregorio GV, Choudhuri K, Ma Y, Pensati P, Iorio R, Grant P, et al. Mimicry Between the Hepatitis C Virus Polyprotein and Antigenic Targets of Nuclear and Smooth Muscle Antibodies in Chronic Hepatitis C Virus Infection. Clin Exp Immunol (2003) 133(3):404-13. doi: 10.1046/j.1365-2249.2003.02229.x

28. Gregorio GV, Choudhuri K, Ma Y, Vegnente A, Mieli-Vergani G, Vergani D. Mimicry Between the Hepatitis B Virus DNA Polymerase and the Antigenic Targets of Nuclear and Smooth Muscle Antibodies in Chronic Hepatitis B Virus Infection. J Immunol (1999) 162(3):1802-10.

29. Kerkar N, Choudhuri K, Ma Y, Mahmoud A, Bogdanos DP, Muratori L, et al. Cytochrome P4502D6(193-212): A New Immunodominant Epitope and Target of Virus/Self Cross-Reactivity in Liver Kidney Microsomal Autoantibody Type 1-Positive Liver Disease. J Immunol (2003) 170 (3):1481-9. doi: 10.4049/jimmunol.170.3.1481

30. Manns MP, Griffin KJ, Sullivan KF, Johnson EF. LKM-1 Autoantibodies Recognize a Short Linear Sequence in P450IID6, a Cytochrome P-450 Monooxygenase. J Clin Invest (1991) 88(4):1370-8. doi: 10.1172/JCI115443

31. Leone P, Shin EC, Perosa F, Vacca A, Dammacco F, Racanelli V. MHC Class I Antigen Processing and Presenting Machinery: Organization, Function, and Defects in Tumor Cells. J Natl Cancer Inst (2013) 105(16):1172-87. doi: 10.1093/jnci/djt184

32. Roy CR. Immunology: Professional Secrets. Nature (2003) 425(6956):351-2. doi: $10.1038 / 425351 \mathrm{a}$

33. Embgenbroich M, Burgdorf S. Current Concepts of Antigen CrossPresentation. Front Immunol (2018) 9:1643. doi: 10.3389/fimmu.2018.01643

34. Campana S, De Pasquale C, Carrega P, Ferlazzo G, Bonaccorsi I. CrossDressing: An Alternative Mechanism for Antigen Presentation. Immunol Lett (2015) 168(2):349-54. doi: 10.1016/j.imlet.2015.11.002

35. Joly E, Hudrisier D. What is Trogocytosis and What Is Its Purpose? Nat Immunol (2003) 4(9):815. doi: 10.1038/ni0903-815

36. Zeng F, Morelli AE. Extracellular Vesicle-Mediated MHC Cross-Dressing in Immune Homeostasis, Transplantation, Infectious Diseases, and Cancer. Semin Immunopathol (2018) 40(5):477-90. doi: 10.1007/s00281-018-0679-8

37. Burghardt S, Claass B, Erhardt A, Karimi K, Tiegs G. Hepatocytes Induce Foxp3(+) Regulatory T Cells by Notch Signaling. J Leukoc Biol (2014) 96 (4):571-7. doi: 10.1189/jlb.2AB0613-342RR

38. Burghardt S, Erhardt A, Claass B, Huber S, Adler G, Jacobs T, et al. Hepatocytes Contribute to Immune Regulation in the Liver by Activation of the Notch Signaling Pathway in T Cells. J Immunol (2013) 191(11):557482. doi: $10.4049 /$ jimmunol.1300826

39. Carambia A, Frenzel C, Bruns OT, Schwinge D, Reimer R, Hohenberg H, et al. Inhibition of Inflammatory CD4 T Cell Activity by Murine Liver Sinusoidal Endothelial Cells. J Hepatol (2013) 58(1):112-8. doi: 10.1016/ j.jhep.2012.09.008

40. Kruse N, Neumann K, Schrage A, Derkow K, Schott E, Erben U, et al. Priming of CD4+ T Cells by Liver Sinusoidal Endothelial Cells Induces CD25low Forkhead Box Protein 3- Regulatory T Cells Suppressing Autoimmune Hepatitis. Hepatology (2009) 50(6):1904-13. doi: 10.1002/hep.23191

41. Bowen DG, Zen M, Holz L, Davis T, McCaughan GW, Bertolino P. The Site of Primary T Cell Activation Is a Determinant of the Balance Between Intrahepatic Tolerance and Immunity. J Clin Invest (2004) 114(5):701-12. doi: 10.1172/JCI21593

42. Bozward A, Ce M, Dell'oro L, Oo YH, Ronca V. Breakdown in Hepatic Tolerance and Its Relation to Autoimmune Liver Diseases. Minerva Gastroenterol (Torino) (2021) 67. doi: 10.23736/S2724-5985.21.02853-1

43. Horst AK, Kumashie KG, Neumann K, Diehl L, Tiegs G. Antigen Presentation, Autoantibody Production, and Therapeutic Targets in 
Autoimmune Liver Disease. Cell Mol Immunol (2021) 18(1):92-111. doi: 10.1038/s41423-020-00568-6

44. Vuerich M, Wang N, Kalbasi A, Graham JJ, Longhi MS. Dysfunctional Immune Regulation in Autoimmune Hepatitis: From Pathogenesis to Novel Therapies. Front Immunol (2021) 12:746436. doi: 10.3389/fimmu.2021. 746436

45. Chen YY, Jeffery HC, Hunter S, Bhogal R, Birtwistle J, Braitch MK, et al. Human Intrahepatic Regulatory T Cells Are Functional, Require IL-2 From Effector Cells for Survival, and Are Susceptible to Fas Ligand-Mediated Apoptosis. Hepatology (2016) 64(1):138-50. doi: 10.1002/hep.28517

46. Longhi MS, Mieli-Vergani G, Vergani D. Regulatory T Cells in Autoimmune Hepatitis: An Updated Overview. J Autoimmun (2021) 119:102619. doi: 10.1016/j.jaut.2021.102619

47. Wan YY, Flavell RA. Regulatory T-Cell Functions Are Subverted and Converted Owing to Attenuated Foxp3 Expression. Nature (2007) 445 (7129):766-70. doi: 10.1038/nature05479

48. Xu L, Kitani A, Fuss I, Strober W. Cutting Edge: Regulatory T Cells Induce CD4+CD25-Foxp3- T Cells or Are Self-Induced to Become Th17 Cells in the Absence of Exogenous TGF-Beta. J Immunol (2007) 178(11):6725-9. doi: 10.4049/jimmunol.178.11.6725

49. Adler LN, Jiang W, Bhamidipati K, Millican M, Macaubas C, Hung SC, et al. The Other Function: Class II-Restricted Antigen Presentation by B Cells. Front Immunol (2017) 8:319. doi: 10.3389/fimmu.2017.00319

50. DiLillo DJ, Horikawa M. Tedder TF. B-Lymphocyte Effector Functions in Health and Disease. Immunol Res (2011) 49(1-3):281-92. doi: 10.1007/ s12026-010-8189-3

51. Shlomchik MJ. Sites and Stages of Autoreactive B Cell Activation and Regulation. Immunity (2008) 28(1):18-28. doi: 10.1016/j.immuni. 2007.12.004

52. Beland K, Marceau G, Labardy A, Bourbonnais S, Alvarez F. Depletion of B Cells Induces Remission of Autoimmune Hepatitis in Mice Through Reduced Antigen Presentation and Help to T Cells. Hepatology (2015) 62 (5):1511-23. doi: 10.1002/hep.27991

53. Franco A, Barnaba V, Natali P, Balsano C, Musca A, Balsano F. Expression of Class I and Class II Major Histocompatibility Complex Antigens on Human Hepatocytes. Hepatology (1988) 8(3):449-54. doi: 10.1002/ hep. 1840080302

54. Herkel J, Jagemann B, Wiegard C, Lazaro JF, Lueth S, Kanzler S, et al. MHC Class II-Expressing Hepatocytes Function as Antigen-Presenting Cells and Activate Specific CD4 T Lymphocyutes. Hepatology (2003) 37(5):1079-85. doi: 10.1053/jhep.2003.50191

55. French SW. Change in Nomenclature for the Immunologic Synapse From Troxis Necrosis to Trogocytosis. Exp Mol Pathol (2017) 103(2):162. doi: 10.1016/j.yexmp.2017.08.001

56. Hudrisier D, Riond J, Mazarguil H, Gairin JE, Joly E. Cutting Edge: CTLs Rapidly Capture Membrane Fragments From Target Cells in a TCR Signaling-Dependent Manner. J Immunol (2001) 166(6):3645-9. doi: 10.4049/jimmunol.166.6.3645

57. French SW, Lu JG. Piecemeal Necrosis is Due to the Immunologic Synapse Formation and Internalization of Intact TCR-MHC II Complexes by CD4 T Cells. Exp Mol Pathol (2018) 105(1):150-2. doi: 10.1016/j.yexmp. 2018.07.004

58. Szabo G, Momen-Heravi F. Extracellular Vesicles in Liver Disease and Potential as Biomarkers and Therapeutic Targets. Nat Rev Gastroenterol Hepatol (2017) 14(8):455-66. doi: 10.1038/nrgastro.2017.71

59. Cocucci E, Meldolesi J. Ectosomes and Exosomes: Shedding the Confusion Between Extracellular Vesicles. Trends Cell Biol (2015) 25(6):364-72. doi: 10.1016/j.tcb.2015.01.004

60. Alonso R, Rodriguez MC, Pindado J, Merino E, Merida I, Izquierdo M. Diacylglycerol Kinase Alpha Regulates the Secretion of Lethal Exosomes Bearing Fas Ligand During Activation-Induced Cell Death of T Lymphocytes. J Biol Chem (2005) 280(31):28439-50. doi: 10.1074/jbc.M501112200

61. Muntasell A, Berger AC, Roche PA. T Cell-Induced Secretion of MHC Class II-Peptide Complexes on B Cell Exosomes. EMBO J (2007) 26(19):4263-72. doi: 10.1038/sj.emboj.7601842

62. Shelke GV, Yin Y, Jang SC, Lasser C, Wennmalm S, Hoffmann HJ, et al. Endosomal Signalling via Exosome Surface TGFbeta-1. J Extracell Vesicles (2019) 8(1):1650458. doi: 10.1080/20013078.2019.1650458
63. Scholzel K, Schildberg FA, Welz M, Borner C, Geiger S, Kurts C, et al. Transfer of MHC-Class-I Molecules Among Liver Sinusoidal Cells Facilitates Hepatic Immune Surveillance. J Hepatol (2014) 61(3):600-8. doi: 10.1016/j.jhep.2014.04.028

64. Crispe IN. Liver Antigen-Presenting Cells. J Hepatol (2011) 54(2):357-65. doi: 10.1016/j.jhep.2010.10.005

65. Longhi MS, Ma Y, Bogdanos DP, Cheeseman P, Mieli-Vergani G, Vergani D. Impairment of CD4(+)CD25(+) Regulatory T-Cells in Autoimmune Liver Disease. J Hepatol (2004) 41(1):31-7. doi: 10.1016/j.jhep.2004.03.008

66. Ferri S, Longhi MS, De Molo C, Lalanne C, Muratori P, Granito A, et al. A Multifaceted Imbalance of T Cells With Regulatory Function Characterizes Type 1 Autoimmune Hepatitis. Hepatology (2010) 52(3):999-1007. doi: $10.1002 /$ hep. 23792

67. Liberal R, Grant CR, Holder BS, Cardone J, Martinez-Llordella M, Ma Y, et al. In Autoimmune Hepatitis Type 1 or the Autoimmune HepatitisSclerosing Cholangitis Variant Defective Regulatory T-Cell Responsiveness to IL-2 Results in Low IL-10 Production and Impaired Suppression. Hepatology (2015) 62(3):863-75. doi: 10.1002/hep.27884

68. Longhi MS, Ma Y, Mitry RR, Bogdanos DP, Heneghan M, Cheeseman P, et al. Effect of CD4+ CD25+ Regulatory T-Cells on CD8 T-Cell Function in Patients With Autoimmune Hepatitis. J Autoimmun (2005) 25(1):63-71. doi: 10.1016/j.jaut.2005.05.001

69. Manigold T, Racanelli V. T-Cell Regulation by CD4 Regulatory T Cells During Hepatitis B and C Virus Infections: Facts and Controversies. Lancet Infect Dis (2007) 7(12):804-13. doi: 10.1016/S1473-3099(07)70289-X

70. Deaglio S, Dwyer KM, Gao W, Friedman D, Usheva A, Erat A, et al. Adenosine Generation Catalyzed by CD39 and CD73 Expressed on Regulatory T Cells Mediates Immune Suppression. J Exp Med (2007) 204 (6):1257-65. doi: 10.1084/jem.20062512

71. Dwyer KM, Hanidziar D, Putheti P, Hill PA, Pommey S, McRae JL, et al. Expression of CD39 by Human Peripheral Blood CD4+ CD25+ T Cells Denotes a Regulatory Memory Phenotype. Am J Transplant (2010) 10 (11):2410-20. doi: 10.1111/j.1600-6143.2010.03291.x

72. Kobie JJ, Shah PR, Yang L, Rebhahn JA, Fowell DJ, Mosmann TR. T Regulatory and Primed Uncommitted CD4 T Cells Express CD73, Which Suppresses Effector CD4 T Cells by Converting 5'-Adenosine Monophosphate to Adenosine. J Immunol (2006) 177(10):6780-6. doi: 10.4049/jimmunol.177.10.6780

73. Grant CR, Liberal R, Holder BS, Cardone J, Ma Y, Robson SC, et al. Dysfunctional CD39(POS) Regulatory T Cells and Aberrant Control of THelper Type 17 Cells in Autoimmune Hepatitis. Hepatology (2014) 59 (3):1007-15. doi: 10.1002/hep.26583

74. Ichiki Y, Aoki CA, Bowlus CL, Shimoda S, Ishibashi H, Gershwin ME. T Cell Immunity in Autoimmune Hepatitis. Autoimmun Rev (2005) 4(5):315-21. doi: 10.1016/j.autrev.2005.01.005

75. Senaldi G, Lobo-Yeo A, Mowat AP, Mieli-Vergani G, Vergani D. Class I and Class II Major Histocompatibility Complex Antigens on Hepatocytes: Importance of the Method of Detection and Expression in Histologically Normal and Diseased Livers. J Clin Pathol (1991) 44(2):107-14. doi: $10.1136 /$ jcp.44.2.107

76. Delneste Y, Charbonnier P, Herbault N, Magistrelli G, Caron G, Bonnefoy JY, et al. Interferon-Gamma Switches Monocyte Differentiation From Dendritic Cells to Macrophages. Blood (2003) 101(1):143-50. doi: 10.1182/ blood-2002-04-1164

77. Schroder K, Hertzog PJ, Ravasi T, Hume DA. Interferon-Gamma: An Overview of Signals, Mechanisms and Functions. J Leukoc Biol (2004) 75 (2):163-89. doi: $10.1189 / \mathrm{jlb} .0603252$

78. Longhi MS, Hussain MJ, Bogdanos DP, Quaglia A, Mieli-Vergani G, Ma Y, et al. Cytochrome P450IID6-Specific CD8 T Cell Immune Responses Mirror Disease Activity in Autoimmune Hepatitis Type 2. Hepatology (2007) 46 (2):472-84. doi: 10.1002/hep.21658

79. Lohr HF, Schlaak JF, Lohse AW, Bocher WO, Arenz M, Gerken G, et al. Autoreactive CD4+ LKM-Specific and Anticlonotypic T-Cell Responses in LKM-1 Antibody-Positive Autoimmune Hepatitis. Hepatology (1996) 24 (6):1416-21. doi: 10.1002/hep.510240619

80. Liberal R, Krawitt EL, Vierling JM, Manns MP, Mieli-Vergani G, Vergani D. Cutting Edge Issues in Autoimmune Hepatitis. J Autoimmun (2016) 75:619. doi: 10.1016/j.jaut.2016.07.005 
81. Terziroli Beretta-Piccoli B, Mieli-Vergani G, Vergani D. Autoimmmune Hepatitis. Cell Mol Immunol (2021) 18(9):1-19. doi: 10.1038/s41423-02100768-8

82. Muratori L, Parola M, Ripalti A, Robino G, Muratori P, Bellomo G, et al. Liver/kidney Microsomal Antibody Type 1 Targets CYP2D6 on Hepatocyte Plasma Membrane. Gut (2000) 46(4):553-61. doi: 10.1136/gut.46.4.553

83. Bettelli E, Carrier Y, Gao W, Korn T, Strom TB, Oukka M, et al. Reciprocal Developmental Pathways for the Generation of Pathogenic Effector TH17 and Regulatory T Cells. Nature (2006) 441(7090):235-8. doi: 10.1038/ nature 04753

84. Zhao L, Tang Y, You Z, Wang Q, Liang S, Han X, et al. Interleukin-17 Contributes to the Pathogenesis of Autoimmune Hepatitis Through Inducing Hepatic Interleukin-6 Expression. PloS One (2011) 6(4):e18909. doi: 10.1371/journal.pone.0018909

85. Ma CS, Deenick EK. Human T Follicular Helper (Tfh) Cells and Disease. Immunol Cell Biol (2014) 92(1):64-71. doi: 10.1038/icb.2013.55

86. Nurieva R, Yang XO, Martinez G, Zhang Y, Panopoulos AD, Ma L, et al. Essential Autocrine Regulation by IL-21 in the Generation of Inflammatory T Cells. Nature (2007) 448(7152):480-3. doi: 10.1038/nature05969

87. Zeng H, Cohen S, Guy C, Shrestha S, Neale G, Brown SA, et al. Mtorc1 and Mtorc2 Kinase Signaling and Glucose Metabolism Drive Follicular Helper T Cell Differentiation. Immunity (2016) 45(3):540-54. doi: 10.1016/ j.immuni.2016.08.017

88. Abe K, Takahashi A, Imaizumi H, Hayashi M, Okai K, Kanno Y, et al. Interleukin21 Plays a Critical Role in the Pathogenesis and Severity of Type I Autoimmune Hepatitis. Springerplus (2016) 5(1):777. doi: 10.1186/s40064-016-2512-y

89. Thomas-Dupont P, Remes-Troche JM, Izaguirre-Hernandez IY, SanchezVargas LA, Maldonado-Renteria Mde J, Hernandez-Flores KG, et al. Elevated Circulating Levels of IL-21 and IL-22 Define a Cytokine Signature Profile in Type 2 Autoimmune Hepatitis Patients. Ann Hepatol (2016) 15(4):550-8. doi: 10.5604/16652681.1203152

90. Linterman MA, Pierson W, Lee SK, Kallies A, Kawamoto S, Rayner TF, et al. Foxp3+ Follicular Regulatory T Cells Control the Germinal Center Response. Nat Med (2011) 17(8):975-82. doi: 10.1038/nm.2425

91. Wen L, Ma Y, Bogdanos DP, Wong FS, Demaine A, Mieli-Vergani G, et al. Pediatric Autoimmune Liver Diseases: The Molecular Basis of Humoral and Cellular Immunity. Curr Mol Med (2001) 1(3):379-89. doi: 10.2174/ 1566524013363672

92. Czaja AJ. Autoimmune Hepatitis. Part A: Pathogenesis. Expert Rev Gastroenterol Hepatol (2007) 1(1):113-28. doi: 10.1586/17474124.1.1.113

93. Vergani D, Terziroli Beretta-Piccoli B, Mieli-Vergani G. A Reasoned Approach to the Treatment of Autoimmune Hepatitis. Dig Liver Dis (2021) 53(11):1381-93. doi: 10.1016/j.dld.2021.05.033

94. Burak KW, Swain MG, Santodomingo-Garzon T, Lee SS, Urbanski SJ, Aspinall AI, et al. Rituximab for the Treatment of Patients With Autoimmune Hepatitis Who Are Refractory or Intolerant to Standard Therapy. Can J Gastroenterol (2013) 27(5):273-80. doi: 10.1155/2013/512624

95. Weiler-Normann C, Schramm C, Quaas A, Wiegard C, Glaubke C, Pannicke $\mathrm{N}$, et al. Infliximab as a Rescue Treatment in Difficult-to-Treat Autoimmune Hepatitis. J Hepatol (2013) 58(3):529-34. doi: 10.1016/j.jhep.2012.11.010

96. Arvaniti P, Giannoulis G, Gabeta S, Zachou K, Koukoulis GK, Dalekos GN. Belimumab Is a Promising Third-Line Treatment Option for Refractory Autoimmune Hepatitis. JHEP Rep (2020) 2(4):100123. doi: 10.1016/ j.jhepr.2020.100123
97. Rosenzwajg M, Lorenzon R, Cacoub P, Pham HP, Pitoiset F, El Soufi K, et al. Immunological and Clinical Effects of Low-Dose Interleukin-2 Across 11 Autoimmune Diseases in a Single, Open Clinical Trial. Ann Rheum Dis (2019) 78(2):209-17. doi: 10.1136/annrheumdis-2018-214229

98. Longhi MS, Hussain MJ, Kwok WW, Mieli-Vergani G, Ma Y, Vergani D. Autoantigen-Specific Regulatory T Cells, a Potential Tool for ImmuneTolerance Reconstitution in Type-2 Autoimmune Hepatitis. Hepatology (2011) 53(2):536-47. doi: 10.1002/hep.24039

99. Streeter HB, Wraith DC. Manipulating Antigen Presentation for AntigenSpecific Immunotherapy of Autoimmune Diseases. Curr Opin Immunol (2021) 70:75-81. doi: 10.1016/j.coi.2021.03.019

100. Dolton G, Zervoudi E, Rius C, Wall A, Thomas HL, Fuller A, et al. Optimized Peptide-MHC Multimer Protocols for Detection and Isolation of Autoimmune T-Cells. Front Immunol (2018) 9:1378. doi: 10.3389/ fimmu.2018.01378

101. Christophersen A. Peptide-MHC Class I and Class II Tetramers: From Flow to Mass Cytometry. HLA (2020) 95(3):169-78. doi: 10.1111/tan.13789

102. Hardtke-Wolenski M, Fischer K, Noyan F, Schlue J, Falk CS, Stahlhut M, et al. Genetic Predisposition and Environmental Danger Signals Initiate Chronic Autoimmune Hepatitis Driven by CD4+ T Cells. Hepatology (2013) 58(2):718-28. doi: 10.1002/hep.26380

103. Clemente-Casares X, Blanco J, Ambalavanan P, Yamanouchi J, Singha S, Fandos C, et al. Expanding Antigen-Specific Regulatory Networks to Treat Autoimmunity. Nature (2016) 530(7591):434-40. doi: 10.1038/nature16962

104. Umeshappa CS, Singha S, Blanco J, Shao K, Nanjundappa RH, Yamanouchi J, et al. Suppression of a Broad Spectrum of Liver Autoimmune Pathologies by Single Peptide-MHC-Based Nanomedicines. Nat Commun (2019) 10 (1):2150. doi: 10.1038/s41467-019-09893-5

105. Carambia A, Freund B, Schwinge D, Bruns OT, Salmen SC, Ittrich H, et al. Nanoparticle-Based Autoantigen Delivery to Treg-Inducing Liver Sinusoidal Endothelial Cells Enables Control of Autoimmunity in Mice. $J$ Hepatol (2015) 62(6):1349-56. doi: 10.1016/j.jhep.2015.01.006

106. Nazimek K, Bryniarski K. Approaches to Inducing Antigen-Specific Immune Tolerance in Allergy and Autoimmunity: Focus on Antigen-Presenting Cells and Extracellular Vesicles. Scand J Immunol (2020) 91(6):e12881. doi: $10.1111 /$ sji. 12881

Conflict of Interest: The authors declare that the research was conducted in the absence of any commercial or financial relationships that could be construed as a potential conflict of interest.

Publisher's Note: All claims expressed in this article are solely those of the authors and do not necessarily represent those of their affiliated organizations, or those of the publisher, the editors and the reviewers. Any product that may be evaluated in this article, or claim that may be made by its manufacturer, is not guaranteed or endorsed by the publisher.

Copyright (c) 2022 Fasano, Malerba, Prete, Solimando, Buonavoglia, Silvestris, Leone and Racanelli. This is an open-access article distributed under the terms of the Creative Commons Attribution License (CC BY). The use, distribution or reproduction in other forums is permitted, provided the original author(s) and the copyright owner(s) are credited and that the original publication in this journal is cited, in accordance with accepted academic practice. No use, distribution or reproduction is permitted which does not comply with these terms. 